МОДЕЛЮВАННЯ СИСТЕМИ УПРАВЛІННЯ У ТЕЛЕКОМУНІКАЦІЙНІЙ ІНДУСТРІЇ

MANAGEMENT SYSTEM MODELING IN THE TELECOMMUNICATIONS INDUSTRY

Удк 338.532:330.101

https://doi.org/10.32843/infrastruct36-86

\section{Дименко Р.А.}

к.е.н., завідувач кафредри

підприємництва, торгівлі

та біржової діяльності

Навчально-науковий інститут

менеджменту та підприємництва

Державний університет телекомунікацій
Ключовою характеристикою телекомунікаційної індустрії $є$ технологічність як вміння максимально раціонально і ефективно створювати або виконувати телекомунікаційні товари, послуги та сервіси, оперативно й гнучко перебудовуючись відповідно до вимог споживчого ринку. А ключовими компетенціями для суб'єктів телекомунікаційної індустрії можуть бути компетениії в сорерах розвитку науки, техніки, технології, економічної, фрінансової, соціальної, антикризовоі діяльності й інших фуннкцій та телекомунікаційних бізнес-процесів. Оскільки ключові компетенції - це індивідуальний портрет бізнесу у телекомунікаційній індустрії, то кожен суб'єкт господарювання фрормує свій портфель компетенцій і виділяє у ньому найбільш пріоритетні для поточної та стратегічної діяльності.

Ключові слова: системи управління, діджиталізація, інформаційно-телекомунікаційна галузь, бізнес-процеси, емерджентність.

Ключевой характеристикой телекоммуникационной индустрии является технологич- ность как умение максимально рационально и эфффективно создавать или выполнять телекоммуникационные товары, услуги и сервисы, оперативно и гибко перестраиваясь в соответствии с требованиями потребительского рынка. А ключевыми компетенциями для субъектов телекоммуникационной индустрии могут быть компетенции в сорерах развития науки, техники, технологии, экономической, финансовой, социальной, антикризисной деятельности и других фрункций и телекоммуникационных бизнес-процессов. Поскольку ключевые компетенции - это индивидуальный порmpem бизнеса в телекоммуникационной индустрии, то каждый субъект хозяйствования формирует свой порторель компетенций и выделяет в нем наиболее приоритетные для текущей и стратегической деятельности.

Ключевые слова: системы управления, диджитализация, информационно-телекоммуникационная отрасль, бизнес-процессы, эмерджентность

The key characteristic of the telecommunications industry is manufacturability as the ability to create or perform telecommunications goods, services and services as efficiently and effectively as possible, quickly and flexibly restructuring in accordance with the requirements of the consumer market. The key competencies for the telecommunications industry may be competencies in the areas of science, technology, economic, financial, social, crisis management and other functions and telecommunications business processes. As key competencies are an individual portrait of the business in the telecommunications industry, each business entity forms its own portfolio of competencies and identifies in it the highest priorities for current and strategic activities. The main goal of this paper is to determine the scientific and methodological support of the management system in the telecommunications industry and the development of their key competencies. Organizational management structures in the telecommunications industry are constantly being transformed according to the life cycles of the telecommunications business. The evolution of a business entity from the stage of "origin" to the stage of "maturity" shows that each stage of development of the relevant component must correspond to its management structure. The alternation of these stages of development leads to the need to change the nature of the management structure in the telecommunications industry from: bureaucratic, flexible, democratic, corporate and to a higher democratic level, where administrative management methods change to financial leverage and organizational coordination of independent business units holding. The organizational mechanism of the management system in the telecommunications industry is implemented through the organizational structure of management, which means the unity of stable relationships between elements that provide current and strategic management of functions and processes in the telecommunications industry. The purpose of the structure of the management system is to ensure the sustainable development of the intra-industry socio-economic system through the formation, protection and improvement of methods and algorithms of interconnection and interaction of the system with the external environment and internal elements of the system.

Key words: management systems, digitalization, information and telecommunication branch, business processes, emergence.

Постановка проблеми. Організаційні структури управління у телекомунікаційній індустрії постійно трансорормуються відповідно до життєвих циклів телекомунікаційного бізнесу. Еволюція бізнесу суб'єкта господарювання від стадії «зародження» до стадії «зрілості» показує, що кожній стадії розвитку відповідного компонента повинна відповідати своя структура управління. Чергування цих стадій розвитку призводить до необхідності зміни характеру структури управління у телекомунікаційній індустрії від: бюрократичного, гнучкого, демократичного, корпоративного та до демократичного більш високого рівня, де адміністративні методи управління змінюються на фрінансові важелі впливу і організаційну координацію самостійних бізнес-одиниць у рамках галузевого управлінського холдингу.

Постановка проблеми. Метою статті $€$ визначення науково-методичного забезпечення системи управління на підприємствах телекомунікаційної галузі та розробки їх ключових компетенцій.

Виклад основного матеріалу. Моделювання системи управління у телекомунікаційній індустрії передбачає дослідження будь-якого явища, процесу, системи, дії та сегментної частини шляхом побудови й вивчення їх моделей. Модель - це будьякий образ, уявний або умовний, у вигляді зображення, опису, схеми, креслення, карти, таблиці, графріка, плану, який використовується для визначення, удосконалення, уточнення, проектування або ілюстрації параметрів, властивостей та інших характеристик досліджуваного об'єкта управління.

Виходячи 3 цього, запропонуємо концептуально-структуровану модель системи управління у телекомунікаційній індустрії з інноваційною орієнтацією у вигляді композиційної схеми (рис. 1), яка включає теоретичну та фрункціональну складову. 


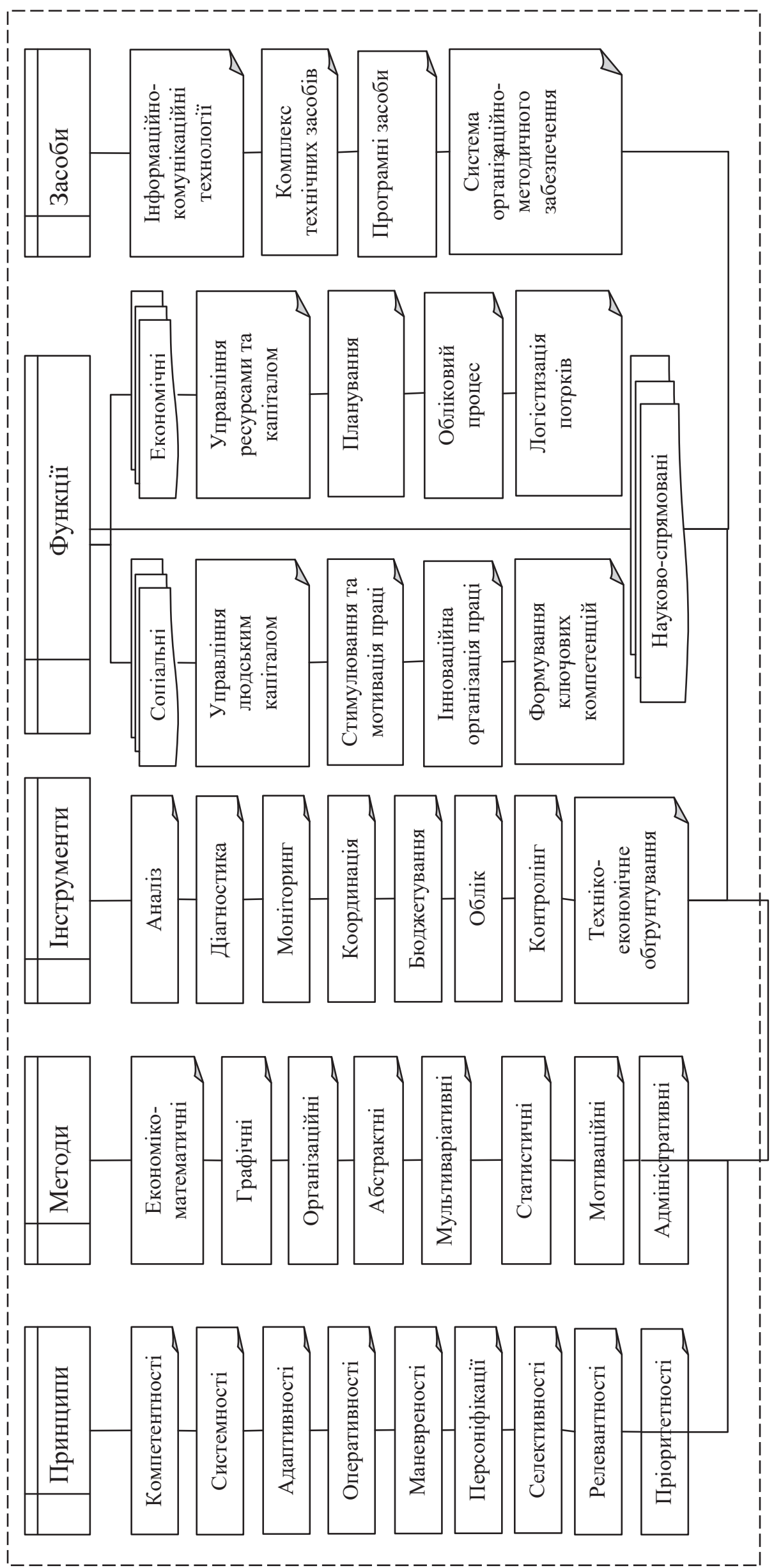

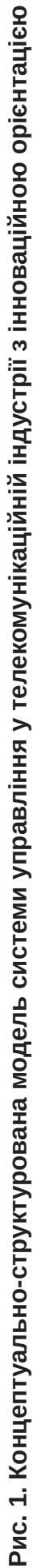


В основу теоретичної складової запропонованої концептуально-структурованої моделі системи управління у телекомунікаційній індустрії з інноваційною орієнтацією покладена ресурсна концепція 3 урахуванням законів, стандартів, методології, нової парадигми, ключових компетенцій. Ресурсна концепція, як було зазначено раніше, спирається на ресурсно-ринковий підхід у його динамічному прояві, що дозволяє забезпечити ринкову привабливість підприємницької діяльності у телекомунікаційній індустрії, ефективність й активну поведінку суб'єкта господарювання на ринку інфрормаційно-комунікаційних послуг і сервісів.

Названі переваги ресурсної концепції на відміну від інших сучасних соціально-економічних теорій ставлять її на перше місце в теоретичному базисі та актуальною в системи управління телекомунікаційної індустрії.

Відомо, що теорія повинна спиратися на відповідну базову методологію, яка забезпечує ефективне фрункціонування всіх ланок певної соціальноекономічної системи, у тому числі управлінської діяльності у внутрішньогалузевому середовищі.

В якості базової методології у сучасному управлінні суб'єктом у телекомунікаційній індустрії зміцнюються тенденції системного підходу та реалізується організаційно-орієнтовна парадигма сучасного управління відповідною ланкою.

Функціональна частина запропонованої концептуально-структурованої моделі системи управління у телекомунікаційній індустрії з інноваційною орієнтацією включає визначені: принципи, методи, інструменти, фрункції управління, а також сучасні засоби, які забезпечують їх есрективне фрункціонування та стратегічний розвиток.

На відміну від діючих і проектованих систем управління у телекомунікаційній індустрії, які насичені численними фрункціями, у змодельованій автором системі виділено базові фрункції управління в галузі з інноваційною орієнтацією:

- соціально-орієнтовна;

- економічно-орієнтовна;

- науково-спрямована.

Функціональна складова моделі обґрунтована теоретичним базисом та актуалізацією соціальноекономічної спрямованості внутрішньогалузевої економіки та системи управління, а також зростаючої тенденцією у розвитку корпоративної науки в телекомунікаційній індустрії.

Сутність науково-спрямованої фрункції позиціонується 3 інноваційними аспектами та полягає в управлінні власними внутрішніми дослідженнями і розробками нових технологій в управлінні телекомунікаційною індустрією та її суб'єктів.

у сучасних умовах, коли макроекономічне середовище телекомунікаційної індустрії має тенденцію до стабілізації, суб'єкти господарювання отримали фрінансові та матеріальні можливості розвивати корпоративну науку як ключовий фрактор підвищення своєї конкурентоспроможності, яка сприятиме стратегічному розвитку галузі у національному та міжнародному просторі.

Крім того, розвиток як академічної, так і прикладної науки галузевого спрямування спирається на державну підтримку на всіх рівнях.

Вищий рівень управління 3 інноваційною орієнтацією може бути забезпечений застосуванням для вирішення стратегічних управлінських завдань автоматизованих інформаційно-комунікаційних технологій, відповідно з якими управлінські рішення починають підкорятися логіці інорормаційно-комунікаційного підходу, в основі якого знаходяться принципи оптимізації та адаптації.

Об'єктивними законами, які регулюють процес управління у телекомунікаційній індустрії $\epsilon$ закон розвитку та синергії, соціально-економічні складові телекомунікаційного бізнесу й ресурсної концепцією, науковий базис методології сучасного управління на галузевому рівні.

Інноваційність запропонованої моделі для телекомунікаційної індустрії у цілому обґрунтовується наступними основними характеристиками:

- сучасною методологією, яка базується на основоположних концепціях теорії систем, синергетики, кібернетики, емерджентності, стратегічного управління, ключових компетенцій, теорії управління;

- оновленою парадигмою стратегічного управління на основі ресурсної концепції розвитку телекомунікаційної індустрії;

- розширеною фрункціонально-орієнтовною системою з введенням науково-спрямованих, ресурсно-регулюючих, соціально-економічних, стратегічних, антикризових та оперативних фрункцій;

- спрямованістю управління у телекомунікаційній індустрії на соціально-економічну відповідальність і соціально-економічні пріоритети відповідно до зростаючою значимістю людського капіталу в галузі;

- високим інтелектуальним рівнем, який обумовленим використанням ключових компетенцій управлінського профрілю у інформаційно-комунікаційних технологіях та сервісах;

- цифрровізацією управлінської діяльності у телекомунікаційній індустрії,

- максимальним використанням телекомунікаційних засобів медіаіндустрії;

- векторною спрямованістю державних національних програм розвитку інфокомунікаційного простору країни.

Інтеграційні аспекти реалізації запропонованої для телекомунікаційної індустрії системи управління 3 інноваційною орієнтацією на рівні господарюючого суб'єкта здійснюються через механізм галузевих ключових компетенцій.

Компетенція - це інформаційно-комунікаційний ресурс, який має особливі властивості, містить 
відповідний досвід роботи у телекомунікаційній індустрії, знання і навички про спосіб організації та управління ресурсами та бізнес-процесами для досягнення поточних і стратегічних цілей у господарській діяльності суб'єкта галузі.

Сукупність компетенцій складають інтелектуальний потенціал у телекомунікаційній індустрії, що $€$ її пріоритетним внутрішньогалузевим стратегічним ресурсом. Носієм такого ресурсу є персонал, якій задіяний у господарських процесах суб'єктів телекомунікаційної індустрії. Галузевим компетенціям властива ієрархія відповідно до ієрархії здібностей і пріоритетності ресурсів, які знаходяться в управлінні суб'єкта телекомунікаційної індустрії.

Використання здібностей суб'єкта телекомунікаційної індустрії призводить до додавання кінцевого продукту певної частки споживчої вартості, яка з'являється в результаті організованої взаємодії та відповідних фрункціональних процесів. Ключова компетенція виступає у вигляді ефективного використання здібностей і ресурсів в господарській системі суб'єкта телекомунікаційній індустрії з певною конфрігурацією.

Галузеві компетенції, які містять комплекс знань, умінь і навичок в області векторних питань розвитку суб'єкта телекомунікаційної індустрії, та мають орієнтацію на науково-технічні, технологічні, фрінансові, економічні, соціальні та інші, називається внутрішньогалузевою ключовою компетенцією. Внутрішньогалузеві ключові компетенції знаходяться на перетині внутрішніх умов телекомунікаційного бізнесу і споживчих переваг, це ті знання, застосування яких впливає на отримання максимальної частки споживної вартості у макроекономічному середовищі. Саме збільшення додаткової споживної вартості за рахунок розвитку внутрішньогалузевої компетенції $є$ підставою для отримання стійкої конкурентної переваги на ринку телекомунікаційних товарів, послуг і сервісів.

Таким чином, внутрішньогалузева ключова компетенція надає можливість отримати у конкурентній боротьбі як якісної переваги, яка відносяться до властивостей продукту або послуги, так і кількісного, що відноситься до стійкого фрінансово-економічного становища. Тому, саме доповнення створюваною внутрішньогалузевою ключовою компетенцією споживчої вартості розкриває її синергетичну природу. Внутрішньогалузева ключова компетенція повинна бути універсальною та здатна забезпечити доступ до цілого ряду ринків телекомунікаційних товарів, послуг і сервісів.

$\mathrm{Ha}$ підставі узагальнення наукових праць можна розробити процедуру фрормування внутрішньогалузевих ключових компетенцій для телекомунікаційної індустрії.

Формування ключових компетенцій з точки зору споживчої вартості повинно включати відповідні етапи (рис. 2). Методика розробки внутрішньогалузевих ключових компетенцій з точки зору внутрішніх можливостей суб'єкта телекомунікаційної індустрії представлена на рис. 3. При цьому особливе значення має виявлення фракторів зовнішнього середовища, фрормування профрілю конкуренції на відповідних сегментах ринку телекомунікаційних товарів, послуг і сервісів, які визначають стратегічні можливості суб'єкта господарювання.

Кожен суб'єкт телекомунікаційної індустрії володіє відмінними характеристиками, але необхідно виділити загальні тенденції галузевого ринку, які впливають на стратегію розвитку галузі:

- зниження темпів зростання ринку телекомунікаційних товарів, послуг і сервісів;

- зміна якості попиту та посилення фрактору персоналізації;

- підвищення вимог до якості телекомунікаційних товарів, послуг і сервісів;

- посилення вимог до швидкості і термінів виробництва телекомунікаційних товарів та надання послуг і сервісів;

- зростання кількості посередників;

- зниження бар'єрів входу на телекомунікаційний ринок;

- десріцит висококваліфрікованих кадрів;

- відсутність соціально-психологічної підтримки працівників, які задіяні у операційній діяльності суб'єктів телекомунікаційної індустрії.

Основним завданням суб'єкта телекомунікаційної індустрії є фрормування ключових компетенцій на основі сорормованої стратегії розвитку галузі. Конкурентоспроможність суб'єкта телекомунікаційної індустрії визначається ефрективним використанням потенціалу:

- виробничо-збутового;

- науково-технічного;

- кадрового.

Ключові компетенції суб'єкта господарювання повинні бути розроблені на основі стратегічних пріоритетів розвитку телекомунікаційної індустрії.

Організаційний механізм системи управління у телекомунікаційній індустрії реалізується через організаційну структуру управління, під якою розуміється єдність стійких взаємозв'язків між елементами, які забезпечують поточне та стратегічне управління фрункціями й процесами, що протікають в діяльності суб'єктів телекомунікаційної індустрії. Цільове призначення структури системи управління - забезпечити стійкий розвиток внутрішньогалузевої соціально-економічної системи за допомогою фрормування, охорони та вдосконалення способів й алгоритмів взаємозв'язку і взаємодії системи з зовнішнім середовищем і внутрішніми елементами системи. За цільовим призначенням також пов'язана і здатність адаптації структури системи управління у телекомунікаційній індустрії до умов зовнішнього середовища $з$ найменшими 
Етапи формування ключових компетенцій у телекомунікаційній галузі 3 точки зору споживчої вартості

Визначення базової ідеї бізнесу у телекомунікаційній сфері

Визначення місії, стратегічних пріоритетів, цілей галузевих суб’єктів

\begin{tabular}{c|}
\hline Формування інструментальної підтримки \\
\hline
\end{tabular}

Стратегічний аналіз макро- та мікросередовища телекомунікаційної індустрії

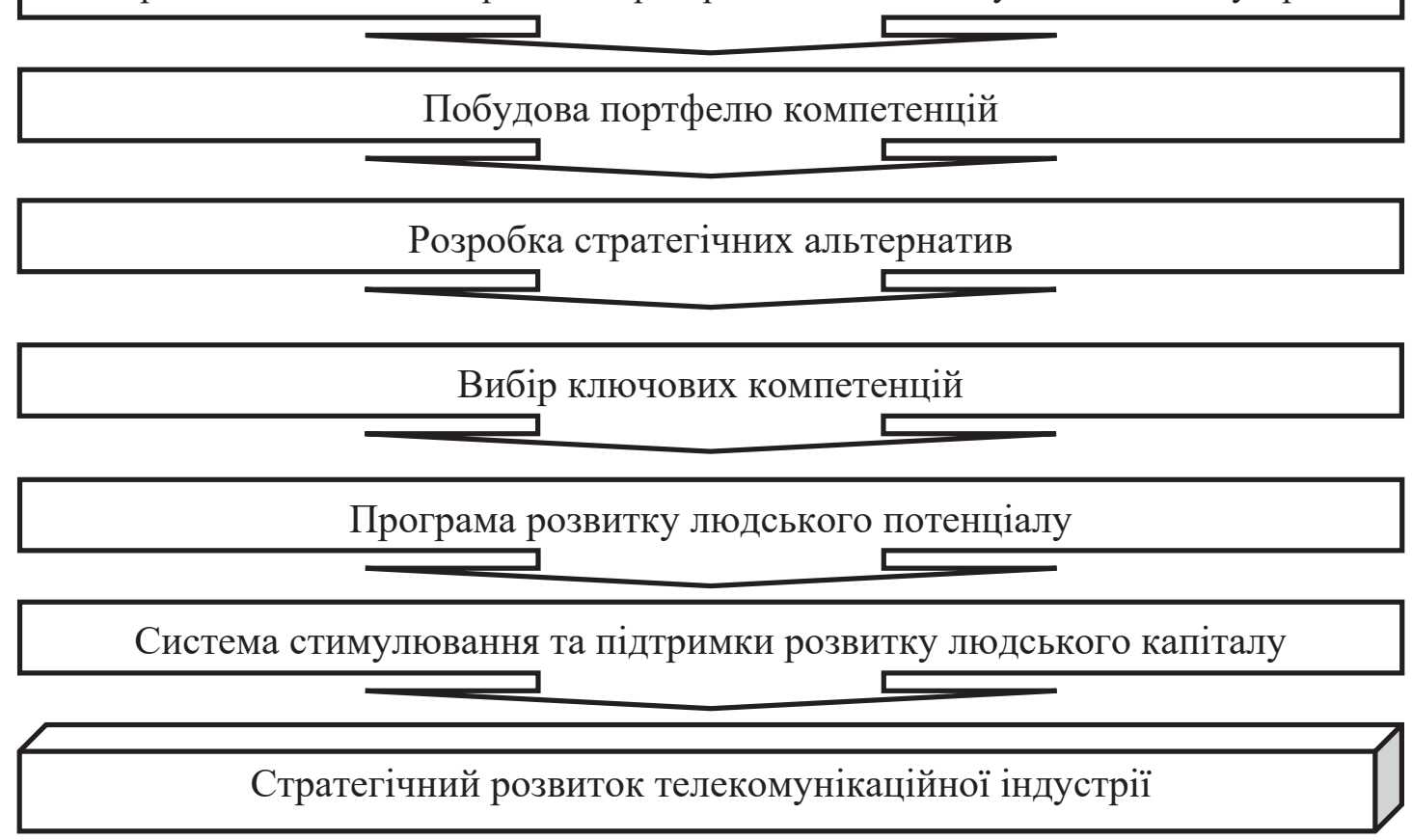

Рис. 2. Етапи формування ключових компетенцій у телекомунікаційній галузі з точки зору споживчої вартості

витратами тимчасових, трудових, матеріальних і фрінансових ресурсів.

Сутність і властивості структури внутрішньогалузевого управління визначають такі основні характеристики суб'єкта телекомунікаційної індустрії: стійкість, раціональність, системність, адаптивність, цілісність, гнучкість, керованість, комунікативність, надійність, корпоративна культура. Управлінська структура вирішує завдання внутрішньогалузевої інтеграції та комунікації на ринку телекомунікації.

Організаційне проектування, використання нових моделей і структур управління у телекомунікаційній індустрії постає найважливішим напрямом розвитку системи управління у галузі.

Висновки $з$ проведеного дослідження. Таким чином сорормовані та обґрунтовані підходи до моделювання системи управління у телекомунікаційній індустрії враховують критичну оцінку діючих моделей управління, синтез та семантичну взаємодію елементів управління, що впливають на ефективність господарської діяльності з урахуванням системних принципів, фрункцій, важелів та інструментів, які забезпечують вирішення визначених цілей стратегічного розвитку суб'єктів телекомунікаційної індустрії в умовах європейської інтеграції. В основу теоретико-методологічного базису системи управління у телекомунікаційній сорері об'єктивно вбудовується сучасна парадигма, яка орієнтована на соціальну мотивацію економічних результатів господарювання. Моделювання системи управління у телекомунікаційній індустрії надає можливість досліджувати відповідні об'єкти, явища та процеси шляхом сегментного поділу їх компонентів, що забезпечить виявлення сильних та слабких сторін діяльності суб'єктів. Процес модулювання повинен 

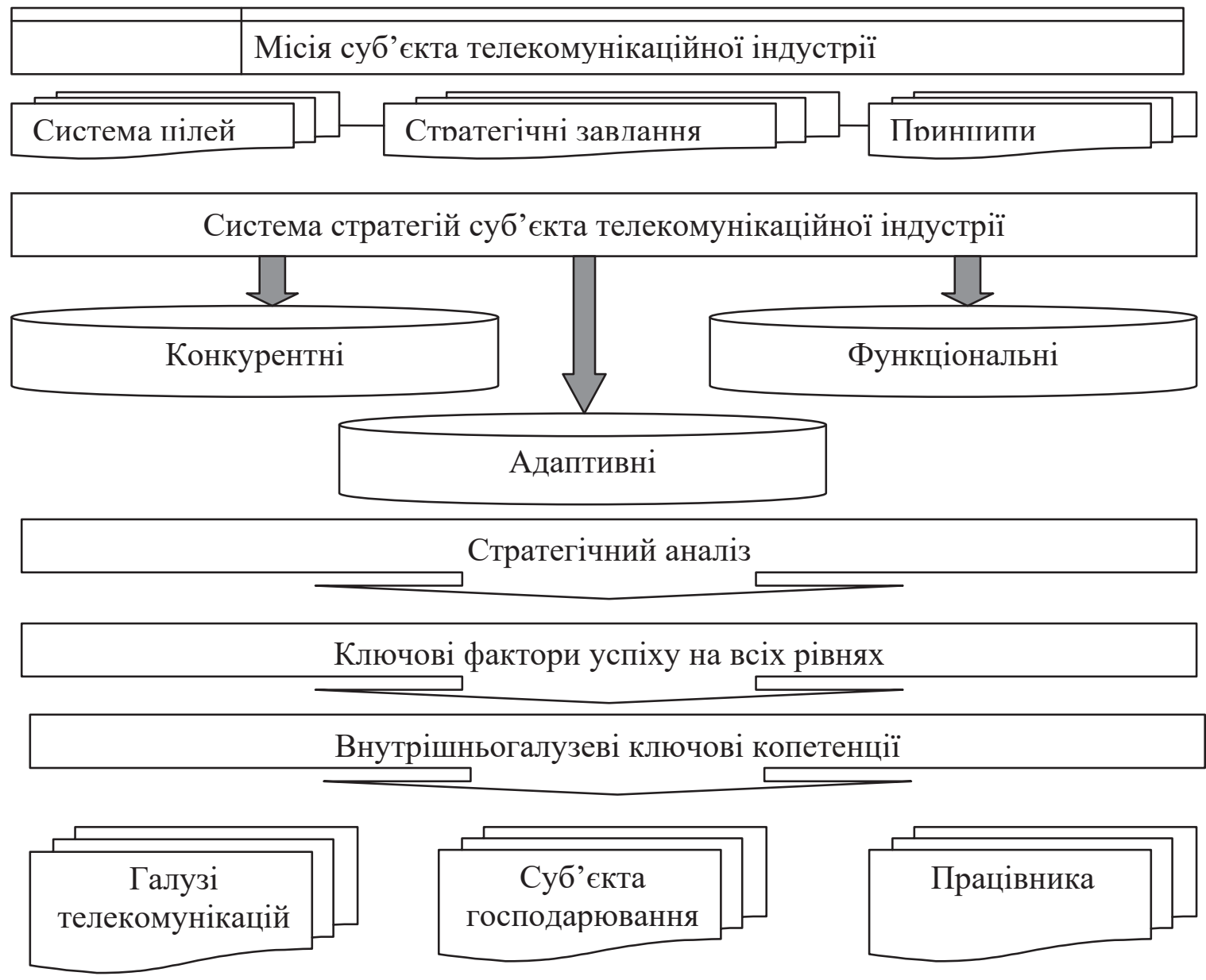

Рис. 3. Методика розробки внутрішньогалузевих ключових компетенцій з точки зору внутрішніх можливостей суб'єкта телекомунікаційної індустрії

враховувати принципи змістовності, незалежності, дедуктивності, індуктивності, селективності, динамічності та комплексності. Дослідження процесу управління враховує специорічні особливості фрункціонування суб'єктів, які фрункціонують на ринку інфрормаційно-комунікаційних послуг і сервісів з урахуванням позиціювання у ринковому середовищі.

\section{БІБЛІОГРАФІЧНИЙ СПИСОК:}

1. Побережець О.В. Теоретико-методологічні та практичні засади дослідження системи управління результатами діяльності промислового підприємства : монограсрія. Херсон : Видавництво : Грінь Д.С., 2016. 500 c.

2. Bertalanffy L. von. General System Theory - A Critical Review. General Systems. Vol. VII. 1962. P. 1-20.

3. Горбань О.М., Бахрушин В.Є. Основи теорії систем і системного аналізу. Запоріжжя : ГУ «3І-ДМУ», 2004. 204 с.
4. Інноваційна економіка: теоретичні та практичні аспекти : монограсрія. Вип. 3 / за ред. д.е.н., доц. Коваленко О. М., д.е.н., проф. Є.І. Масленнікова. Херсон: ОЛДІ-ПЛЮс, 2018. 634 с.

\section{REFERENCES:}

1. Poberezhets O.V. Teoretyko-metodolohichni ta praktychni zasady doslidzhennia systemy upravlinnia rezultatamy diialnosti promyslovoho pidpryiemstva : monohrafiia. Kherson : Vydavnytstvo : Hrin D.S., 2016. $500 \mathrm{p}$.

2. Bertalanffy L. von. General System Theory - A Critical Review. General Systems. Vol. VII. 1962. P. 1-20.

3. Horban O.M., Bakhrushyn V.Ye. Osnovy teorii system i systemnoho analizu. Zaporizhzhia : HU «ZIDMU», 2004. 204 p.

4. Innovatsiina ekonomika: teoretychni ta praktychni aspekty : monohrafiia. Vol. 3 / za red. d.e.n., dots. Kovalenko O. M., d.e.n., prof. Ye.I. Maslennikova. Kherson: OLDI-PLIUS, 2018. 634 p. 
$\mathrm{PhD}$ in Economic sciences, Associate Professor,

Head of the Department of Enterprise, Trade and Exchange Activities State University of Telecommunications

\section{MANAGEMENT SYSTEM MODELING IN THE TELECOMMUNICATIONS INDUSTRY}

Urgency of the research. The key characteristic of the telecommunications industry is manufacturability as the ability to create or perform telecommunications goods, services and services as efficiently and effectively as possible, quickly and flexibly restructuring in accordance with the requirements of the consumer market. The key competencies for the telecommunications industry may be competencies in the areas of science, technology, economic, financial, social, crisis management and other functions and telecommunications business processes. As key competencies are an individual portrait of the business in the telecommunications industry, each business entity forms its own portfolio of competencies and identifies in it the highest priorities for current and strategic activities.

The main goal of this paper is to determine the scientific and methodological support of the management system in the telecommunications industry and the development of their key competencies.

Findings. Organizational management structures in the telecommunications industry are constantly being transformed according to the life cycles of the telecommunications business. The evolution of a business entity from the stage of "origin" to the stage of "maturity" shows that each stage of development of the relevant component must correspond to its management structure. The alternation of these stages of development leads to the need to change the nature of the management structure in the telecommunications industry from: bureaucratic, flexible, democratic, corporate and to a higher democratic level, where administrative management methods change to financial leverage and organizational coordination of independent business units holding.

Value (originality). The organizational mechanism of the management system in the telecommunications industry is implemented through the organizational structure of management, which means the unity of stable relationships between elements that provide current and strategic management of functions and processes in the telecommunications industry. The purpose of the structure of the management system is to ensure the sustainable development of the intra-industry socio-economic system through the formation, protection and improvement of methods and algorithms of interconnection and interaction of the system with the external environment and internal elements of the system. The ability to adapt the structure of the management system in the telecommunications industry to the conditions of the environment with the lowest cost of time, labor, material and financial resources is also related to the purpose.

The essence and properties of the structure of intra-industry management determine the following main characteristics of the telecommunications industry: stability, rationality, system, adaptability, integrity, flexibility, manageability, communication, reliability, corporate culture. The management structure solves the problem of intra-industry integration and communication in the telecommunications market.

And formed and substantiated approaches to modeling the management system in the telecommunications industry take into account the critical assessment of existing management models, synthesis and semantic interaction of management elements that affect business efficiency, taking into account system principles, functions, levers and tools to address strategic development goals, subjects of the telecommunication industry in the conditions of European integration. The basis of the theoretical and methodological basis of the management system in the telecommunications sector is objectively embedded in a modern paradigm, which is focused on the social motivation of economic performance. Modeling of the control system in the telecommunications industry provides an opportunity to study the relevant objects, phenomena and processes by segmenting their components, which will identify the strengths and weaknesses of the subjects. The modulation process must take into account the principles of content, independence, deductivity, inductance, selectivity, dynamism and complexity. The study of the management process takes into account the specific features of the functioning of entities operating in the market of information and communication services and services, taking into account the positioning in the market environment. 